\title{
The Efficacy of Bismuth-based Quadruple and Sequential Therapies in Helicobacter pylori Eradication
}

\section{Helikobakter pilori Eradikasyonunda Bizmutlu Dörtlü Tedavi ile Bizmutlu Ardışık Tedavinin Etkinliği}

(D) Adil Coşkun ${ }^{1}$, (D) Mustafa Çelik ${ }^{2}$, (D) Altay Kandemir ${ }^{1}$

${ }^{1}$ Aydın Adnan Menderes University Faculty of Medicine, Department of Gastroenterology, Aydın, Turkey

${ }^{2}$ Pamukkale University Faculty of Medicine, Department of Gastroenterology, Denizli, Turkey

Keywords

Helicobacter pylori, quadruple treatment, sequential treatment

Anahtar Kelimeler

Helikobakter pilori, dörtlü tedavi, ardışık tedavi

Received/Geliş Tarihi : 03.07.2019

Accepted/Kabul Tarihi : 21.08.2019

doi:10.4274/meandros.galenos.2019.08831

Address for Correspondence/Yazışma Adresi: Adil Coşkun, Assoc. Prof.,

Aydın Adnan Menderes University Faculty of Medicine, Department of Gastroenterology,

Aydın, Turkey

Phone : +90 5325052494

E-mail : adilcoskun@gmail.com

ORCID ID: orcid.org/0000-0002-1549-5451

(C) Meandros Medical and Dental Journal, Published by Galenos Publishing House.

This is article distributed under the terms of the

Creative Commons Attribution NonCommercial 4.0

International Licence (CC BY-NC 4.0).

\begin{abstract}
Objective: New therapy regimens are needed for Helicobacter pylori (H. pylori) eradication because of increased resistance to the commonly used antibiotics. This study aimed to compare the efficacy of bismuth quadruple therapy versus sequential therapy for $H$. pylori eradication.

Materials and Methods: Patients who presented with dyspepsia complaints and were diagnosed with $\mathrm{H}$. pylori infection by histopathologic examination of biopsies obtained by gastroscopy were evaluated retrospectively. Two hundred and five patients who received bismuth-based quadruple therapy and sequential therapy for $H$. pylori eradication were included in the study. Bismuth-based quadruple therapy group were given pantoprazole $2 \times 40 \mathrm{mg}$, bismuth subcitrate $4 \times 300 \mathrm{mg}$, amoxicillin $2 \times 1000 \mathrm{mg}$ and metronidazole $3 \times 500 \mathrm{mg}$ for 14 days. In the bismuthbased sequential therapy group, the protocol was as follows; pantoprazole $2 \times 40 \mathrm{mg}$ (14 days), bismuth subcitrate 4x300 mg (14 days), amoxicillin 2x1000 mg (first 7 days), metronidazole $3 \times 500 \mathrm{mg}$ (second 7 days) and levofloxacin $1 \times 500 \mathrm{mg}$ (second 7 days). Eradication was determined by stool $H$. pylori Antigen test six weeks after the treatment.

Results: A total of 102 patients in group 1 and 91 patients in group 2 completed the treatment and there was no significant difference between the two groups $(\mathrm{p}=0.310)$. H. pylori eradication rate showed no significant difference between the two groups ( $p=0.093)$, while group 1 attained a better eradication rate than group 2 on intention-to-treat, which was statistically significant $(p=0.033)$.

Conclusion: We achieved better eradication rates with bismuth-based quadruple therapy compared to the sequential therapy. We recommend bismuth-based quadruple regimen as the first-line eradication therapy to avoid drug incompatabilities seen during the sequential regime.
\end{abstract}

Öz

Amaç: Helikobakter pilori ( $H$. pilori) eradikasyon tedavisinde kullanılan antibiyotiklere karşı direncin artması nedeniyle yeni tedavi rejimlerine ihtiyaç duyulmaktadır. Bu çalışmada, H. pilori eradikasyonunda bizmutlu dörtlü tedavi ile bizmutlu ardışık tedavinin etkinliğini karşılaştırmayı amaçladık.

Gereç ve Yöntemler: Dispepsi yakınması ile başvuran, yapılan gastroskopi ile alınan biyopsilerde histolojik inceleme sonrasında $H$. pilori saptanan hastalar retrospektif 
olarak değerlendirildi. Eradikasyon tedavisi olarak bizmutlu dörtlü tedavi ve bizmutlu ardışık tedavi alan 231 hasta çalışmaya alındı. Bizmutlu dörtlü tedavi alan gruba; 14 gün boyunca pantoprazol 2x40 mg, bizmut subsitrate 4x300 mg, amoksisilin 2x1000 mg, metronidazol 3x500 mg (14 gün) verilmişti. Bizmutlu ardışık tedavi alan gruba; pantoprazol 2x40 mg (14 gün), bizmut subsitrate 4x300 mg (14 gün), amoksisilin 2x1000 mg (ilk 7 gün), metronidazol 3x500 mg (ikinci 7 gün), levofloksasin 1x500 mg (ikinci 7 gün) verilmişti. Eradikasyon, tedaviden altı hafta sonra gaitada $H$. pilori Antijen testi ile ölçüldü.

Bulgular: Grup 1'de 102 hasta, grup 2'de 91 hasta tedaviyi tamamlamış ve her iki grup arasında anlamlı bir fark bulunmamıştır $(p=0,310)$. Her iki grup arasında protokol başına eradikasyon oranı açısından anlamlı bir fark bulunmamış $(p=0,093)$, grup 1 rejimi intention-to-treat'de grup 2'ye göre daha iyi eradikasyon oranına ulaşmış ve istatistiksel olarak anlamlı bulunmuştur ( $p=0,033)$.

Sonuç: Bizmut bazlı dörtlü tedavi ile ardışık tedaviye oranla daha iyi bir eradikasyon oranlarına ulaştık. Ardışık tedavi sırasında görülebilen ilaç uyumsuzluğu nedeniyle birinci basamak eradikasyon tedavisinde bizmut bazlı dörtlü tedavi rejiminin kullanılmasını önermekteyiz.

\section{Introduction}

Helicobacter pylori (H. pylori) infection is an important health problem in our country and worldwide. H. pylori is the main cause of chronic gastritis and peptic ulcer disease as well as a major risk factor for gastric cancer and mucosa-associated lymphoid tissue lymphoma $(1,2)$. H. pylori is also associated with extraintestinal diseases such as idiopathic thrombocytopenic purpura, unexplained iron deficiency anemia, Diabetes Mellitus and atherosclerotic cardiovascular disease (3).

Worldwide prevalence of $H$. pylori infection is expected to be 4.4 billion in 2015, although itis decreasing in Western Europe and North America (4).

The efficacy of the recommended first line therapy for $H$. pylori infection, which was the triple therapy including proton pump inhibitors (PPIs), amoxicillin and clarithromycin, decreased in most countries, hence new treatment strategies are needed (5-7). The Maastricht $\mathrm{V}$ consensus meeting recommended bismuth-based quadruple therapy regimens in areas with high clarithromycin and metronidazole resistance (8). Moreover, sequential therapy regimes were also proposed as effective first-line treatment methods, in recent years (9). However, the complexity of the sequential therapy regime is a major disadvantage that threatens its feasibility and success rate.

In this study, we aimed to compare the efficacy of bismuth based quadruple therapy versus sequential therapy for the first-line $H$. pylori eradication therapy.

\section{Materials and Methods}

Study Design and Population
Patients admitted to two centers of
gastroenterology department with dyspepsia
complaints between October 2015 and October

2016 and who underwent endoscopic biopsy for $\mathrm{H}$. pylori infection with the pre-diagnosis of non-ulcer dyspepsia and who were found positive for $H$. pylori infection in biopsy were retrospectively evaluated in the study.

Biopsy specimens from both antrum and corpus were sent for histopathological evaluation. $H$. pylori status was assessed by pathologists using hematoxylin-eosin and Giemsa staining procedures. Two hundred and five patients who received bismuth based quadruple therapy and sequential therapy for $H$. pylori eradication were included in the study. The written informed consent of the patients' was not received due to archival scan and retrospective study. Patient information was obtained from hospital information system and/or patient files. Patients who had stomach malignancy, gastric surgery history, previous $H$. pylori eradication therapy and who were under 18 years of age were excluded from the study. The study was approved by Non-invasive Clinical Research Ethics Committee of Adnan Menderes University Medical Faculty (protocol no: 2016/1009).

\section{Treatment Procedures}

Bismuth based quadruple therapy group (group 1) was given pantoprazole $2 \times 40 \mathrm{mg}$ ( 14 days), bismuth subcitrate $4 \times 300 \mathrm{mg}$ (14 days), amoxicillin $2 \times 1000$ $\mathrm{mg}$ (14 days) and metronidazole $3 \times 500 \mathrm{mg}$ (14 days). Bismuth based sequential therapy group (group 2) was given pantoprazole $2 \times 40 \mathrm{mg}$ (14 days), bismuth subcitrate $4 \times 300 \mathrm{mg}$ (14 days), amoxicillin 2x1000 mg (first 7 days), metronidazole $3 \times 500 \mathrm{mg}$ (second 7 days), levofloxacin $1 \times 500 \mathrm{mg}$ (second 7 days). Eradication was assessed in the stool by $\mathrm{H}$. pylori Antigen test after six weeks of treatment, in the period without taking PPI. The stool assay used was the commercially available diagnostic $H$. pylori Antigen Rapid test 
(Cer Test Biotec S.L. Zaragoza, Spain). Successful eradication was defined as Negative Stool test while eradication failure as Positive Stool test.

\section{Statistical Analysis}

Compliance of age with normal distribution was assessed by Kolmogorov-Smirnov test. Descriptive statistics were shown as mean $\left(25^{\text {th }}-75^{\text {th }}\right.$ percentile) since it did not show normal distribution. MannWhitney $U$ test was applied to compare the groups for age variable. The descriptive statistics of categorical variables were expressed as number (percentage). $H$. pylori eradication rates were assessed with perprotocol (PP) and intention-to-treat (ITT) analyzes. Chi-square analysis was used for comparison with respect to the groups. $\mathrm{P}<0.05$ was considered statistically significant.

\section{Results}

In our retrospective study, 193 (94.1\%) of the 205 patients completed the provided treatment. Twelve patients $(5.9 \%)$ failed to complete the treatment due to gastrointestinal system (GIS) intolerance and non compliance with drugs. GIS intolerance was detected in 4 patients of group 1 and 5 patients of group 2 while drug incompatability in 3 patients of group 2. Demographic data of the patients are shown in table 1. Hundred and two patients in group 1 and 91 patients in group 2 completed treatment and there was no significant difference between the two groups $(p=0.310)$.

Eradication was achieved in 95 patients in group 1 and 78 patients in group 2. Eradication rates of $H$. pylori in ITT and PP analysis were $89.6 \%$ and $93.1 \%$ in group $1,78.8 \%$ and $85.7 \%$ in group 2 , respectively. There was no significant difference between the two groups in terms of PP eradication rate $(p=0.093)$. Group 1 regimen reached a better eradication rate in ITT analysis than group 2 and this was statistically significant $(p=0.033)$ (Table 2$)$.

\section{Discussion}

H. pylori colonization was estimated to increase gastric cancer risk by approximately ten times and determined as a class I carcinogen by the World Health Organization (10). The most commonly used treatment regimen for $H$. pylori worldwide is the triple combination of PPI, amoxicillin, and clarithromycin. However, $H$. pylori eradication rates with this triple treatment regimens decreased significantly in recent years $(11,12)$. H. pylori resistance rates against antibiotics are increasing in most parts of the world. The widespread use of clarithromycin against both $H$. pylori and other bacterial infections (especially upper and lower respiratory tract infections) raised concerns regarding clarithromycin resistance against $H$. pylori, which requires to reconsider the effectiveness of clarithromycin regimen for $\mathrm{H}$. pylori eradication. In a study in Japan, the rate of resistance to clarithromycin increased from $8.7 \%$ to $34.5 \%$ from 1997 to 2008 (13). In various studies conducted in our country, amoxicillin resistance was reported as $0 \%$, clarithromycin resistance as $18.2-41.9 \%$, metronidazole resistance as $35.5-45.5 \%$, tetracycline resistance as $0-9.1 \%$, and levofloxacin resistance as 18.2-29.5\% (14-17).

\begin{tabular}{|c|c|c|c|}
\hline Parameter & $\begin{array}{l}\text { Bismuth based quadruple } \\
\text { therapy group (Group 1) }\end{array}$ & $\begin{array}{l}\text { Bismuth based sequential } \\
\text { therapy group (Group 2) }\end{array}$ & p \\
\hline Number of patients, $n$ & 106 & 99 & - \\
\hline Median age (years) & $45.8 \pm 11.8$ & $44 \pm 12.7$ & NS \\
\hline \multirow{2}{*}{\multicolumn{3}{|c|}{$\begin{array}{l}\text { Gender } \\
\text { Male, } n(\%)\end{array}$}} & \multirow{3}{*}{ NS } \\
\hline & & & \\
\hline Female, n (\%) & $60(56.6)$ & $58(58.6)$ & \\
\hline Number of patients who completed therapy, $\mathrm{n}(\%)$ & $102(96.2)$ & 91 (91.9) & NS \\
\hline Reason to discontinue therapy & & & \multirow{3}{*}{ NS } \\
\hline GIS intolerance $(n)$ & 4 & 5 & \\
\hline Drug incompatability (n) & 0 & 3 & \\
\hline
\end{tabular}




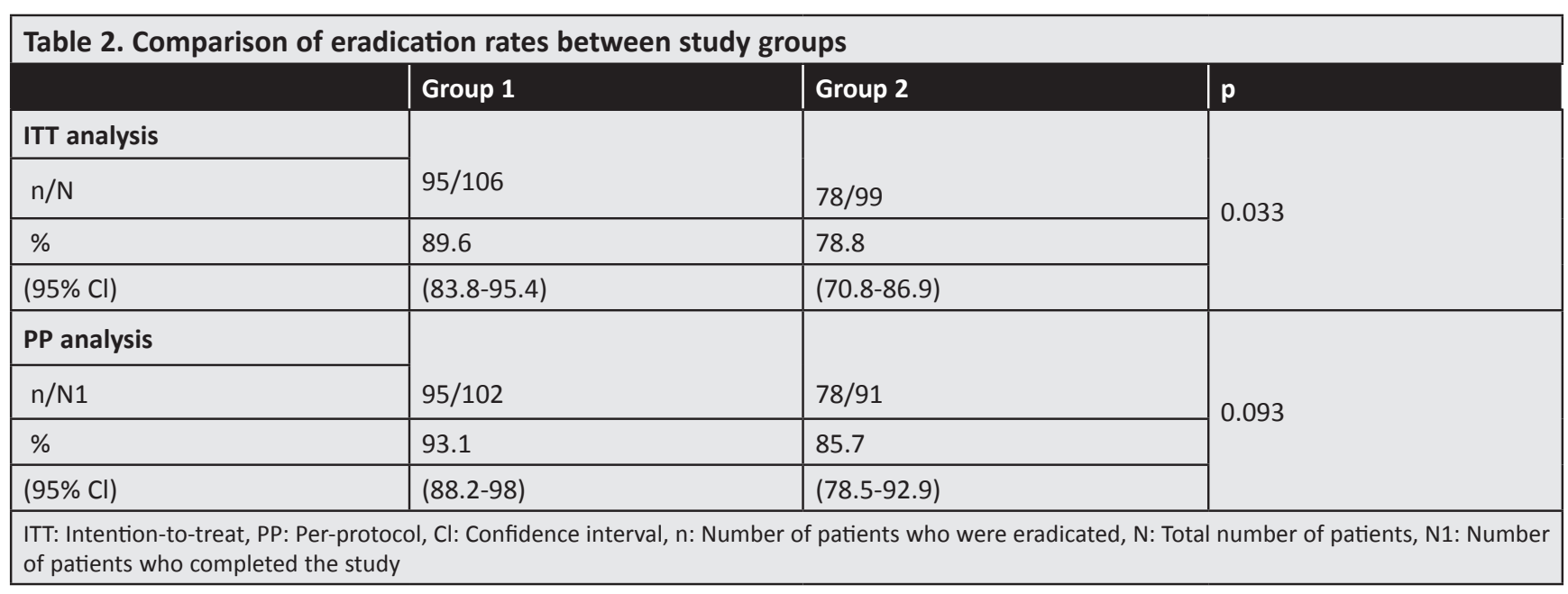

In regions with a resistance rate of clarithromycin exceeding $15 \%$, it is advised in the Maastricht $\mathrm{V}$ Consensus report that, triple treatment with PPIclarithromycin should be discontinued unless clarithromycin resistance is verified by a preliminary susceptibility testing and bismuth quadruple or nonbismuth quadruple concomitant treatments should be given. In addition, bismuth quadruple therapy is recommended as the first-line treatment in areas with high dual resistance to clarithromycin and metronidazole (8).

Bismuth is known to have cytoprotective effects in addition to antimicrobial effects on $\mathrm{H}$. pylori in the gastric mucosa. Up to now, resistance against bismuth has not been reported. Mechanisms of bismuth activity against $H$. pylori is not fully known. Bismuth shows its anti-helicobacter activity by forming complexes in the bacterial wall and periplasmic space, by inhibiting different enzymes of $H$. pylori such as urease, fumarase, phospholipase, by inhibiting adenosine triphosphate synthesis of bacteria, and by preventing adhesion of $H$. pylori onto the gastric mucosa (18). There is a synergy between bismuth salts and antibiotics. For example, when metronidazole and bismuth are used together, metronidazoleresistant $H$. pylori strains become susceptible (19). For this reason, we preferred to administer bismuth in both treatment groups. Different combinations of antibiotics are used in bismuth based quadruple treatments. In our study, we obtained ITT eradication rates of $89.6 \%$ and PP eradication rates of $93.1 \%$ with bismuth based quadruple treatment regimen, which is acceptable for $H$. pylori eradication. In different studies from our country, eradication rates for bismuth based standard quadruple treatment regimens were reported as $81.1 \%$ and $74.6 \%$ in ITT analysis and $86 \%$ and $75.6 \%$ in PP analysis, respectively $(20,21)$. Unlike these studies, we preferred to use amoxicillin instead of tetracycline. Another study used the same therapy regimen as ours and obtained similar eradication rate of $93.9 \%$ in PP analysis (22). The period of treatment in these studies was 14 days. We also preferred a 14 days of treatment on both arms of our study. The Maastricht $\mathrm{V}$ Consensus report also recommends extending the duration of bismuth-based quadruple treatment to 14 days, unless 10-day treatments are locally proven effective (8).

There are various reports about levofloxacincontaining regimens, and the most important concern about the future of these regimens is the potential antibiotic resistance. Eradication success with sequential treatment regimens containing levofloxacin was reported as $81.3 \%$ and $78.0 \%$ in Korea (23) and as $98.4 \%$ and $96.8 \%$ in Italy (24), in PP and ITT analysis, respectively. Levofloxacin resistance in Turkey was reported between $18.2 \%$ and $29.5 \%$ (14-17). Using sequential levofloxacin therapy, Aydın et al. (25) achived $82.5 \%$ eradication with ITT analysis and $86.7 \%$ eradication with PP analysis while Polat et al. (9) achieved $90.2 \%$ and $86.6 \%$ eradication rates, respectiveley. In addition to these regimes, we used bismuth in group 2 . Our eradication rates in group 2 were $78.8 \%$ with ITT analysis and $85.7 \%$ with PP analysis, which were similar to other studies. Four patients in group 1 and 5 patients in group 2 could not complete the treatment because of GIS intolerance 
while 3 patients in group 2 due to drug incompatibility. However, the difference between the groups was not statistically significant. The main limitations of our study are the retrospective design and the absence of investigation on antibiotic resistance. Prospective studies involving also antibiotic susceptibility results may help to improve eradication success.

\section{Conclusion}

As a result, we achieved better eradication rate with bismuth quadruple treatment compared with bismuth sequential treatment in our study. Due to the drug incompatibility observed during sequential treatment, we recommend bismuth based quadruple therapy regimen as the first line eradication treatment.

\section{Ethics}

Ethics Committee Approval: The study was approved by Non-invasive Clinical Research Ethics Committee of Aydın Adnan Menderes University Medical Faculty (protocol no: 2016/1009).

Informed Consent: The written informed consent of the patients' was not received due to archival scan and retrospective study.

Peer-review: Externally and internally peerreviewed.

\section{Authorship Contributions}

Concept: A.C., Design: A.C., Data Collection or Processing: M.Ç., Analysis or Interpretation: M.Ç., Literature Search: A.K., Writing: A.C., A.K.

Conflict of Interest: No conflict of interest was declared by the authors.

Financial Disclosure: The authors declared that this study received no financial support.

\section{References}

1. Morgan DR, Crowe SE. Helicobacter pylori infection. In: Sleisenger MH, Fordtran JS, (Eds). Sleisenger and Fordtran's Gastrointestinal and Liver Disease. 10th ed. Philedelphia: Saunders, 2010; 856-67.

2. Chey WD, Leontiadis GI, Howden CW, Moss SF. ACG clinical guideline: treatment of Helicobacter pylori infection. Am J Gastroenterol 2017; 112: 212-39.

3. Roubaud Baudron C, Franceschi F, Salles N, Gasbarrini A. Extragastric diseases and Helicobacter pylori. Helicobacter 2013; 18: 44-51.

4. Hooi JKY, Lai WY, Ng WK, Suen MMY, Underwood FE, Tanyingoh $D$, et al. Global prevalence of Helicobacter pylori infection: systematic review and meta-analysis. Gastroenterology 2017; 153: 420-9.

5. Sezikli M, Çetinkaya ZA, Güzelbulut F, Yeşil A, Coşgun S, Kurdaş OÖ. Supplementing vitamins $C$ and $E$ to standard triple therapy for the eradication of Helicobacter pylori. J Clin Pharm Ther 2012; 37: 282-5.

6. Avşar E, Tiftikçi A, Poturoğlu S, Erzin Y, Kocakaya O, Dinçer D, et al. A multicenter, randomized, prospective study of 14-day ranitidine bismuth citrate vs. lansoprazole-based triple therapy fort he eradication of Helicobacter pylori in dyspeptic patients. Turk J Gastroenterol 2013; 24: 316-21.

7. Lee JY, Park KS. Optimal First-Line Treatment for Helicobacter pylori Infection: Recent Strategies. Gastroenterol Res Pract 2016; 2016: 9086581.

8. Malfertheiner P, Megraud F, O'Morain CA, Gisbert JP, Kuipers EJ, Axon AT, et al. Management of Helicobacter pylori infection-the Maastricht V/Florence Consensus Report. Gut 2017; 66: 6-30.

9. Polat Z, Kadayifci A, Kantarcioglu M, Ozcan A, Emer O, Uygun A. Comparison of levofloxacin-containing sequential and standard triple therapies for the eradication of Helicobacter pylori. Eur J Intern Med 2012; 23: 165-8.

10. Kusters JG, van Vliet AH, Kuipers EJ. Pathogenesis of Helicobacter pylori infection. Clin Microbiol Rev 2006; 19: 449-90.

11. Kadayifci A, Buyukhatipoglu H, Cemil Savas M, Simsek I. Eradication of Helicobacter pylori with triple therapy: an epidemiologic analysis of trends in Turkey over 10 years. Clin Ther 2006; 28: 1960-6.

12. Onder G, Aydin A, Akarca U, Tekin F, Ozutemiz O, Ilter T. High Helicobacter pylori resistance rate to clarithromycin in Turkey. J Clin Gastroenterol 2007; 41: 747-50.

13. Sasaki M, Ogasawara N, Utsumi K, Kawamura N, Kamiya T, Kataoka $\mathrm{H}$, et al. Changes in 12-year first-line eradication rate of Helicobacter pylori based on tripletherapy with proton pump inhibitor, amoxicillin and clarithromycin. J ClinBiochem Nutr 2010; 47: 53-8.

14. Cagdas U, Otag F, Tezcan S, Sezgin O, Aslan G, Emekdas G. [Detection of Helicobacter pylori and antimicrobial resistance in gastric biopsy specimens]. Mikrobiyol Bul 2012; 46: 398-409.

15. Kalem F, Ozdemir M, Basaranoglu M, Toy H, Baysal B. Helicobacter pylori isolates recovered from antral gastric biopsies of patients with dyspeptic symptoms: Antimicrobial resistance of metronidazole, clarithromycin and amoxicillin. Anatol J Clin Invest ig 2012; 6:37-40.

16. Caliskan R, Tokman HB, Erzin Y, Saribas S, Yuksel P, Bolek BK, et al. Antimicrobial resistance of Helicobacter pylori strains to five antibiotics, including levofloxacin, in Northwestern Turkey. Rev Soc Bras Med Trop 2015; 48: 278-84.

17. Ozbey SB, Cuneyt $O$, Murat K. Antbiotic resistance rates of Helicobacter pylori isolates and the comparison of E-Test and fluorescent in situ hybridization methods for the detection ofclarithromycin resistant strains. Mikrobiyol Bul 2009; 43: 22734.

18. Alkim H, Koksal AR, Boga S, Sen I, Alkim C. Role of Bismuth in the Eradication of Helicobacter pylori. Am J Ther 2017; 24: e751-7. 
19. Dore MP, Graham DY, Mele R, Marras L, Nieddu S, Manca A, et al. Colloidal bismuth subcitrate-based twice-a-day quadruple therapy as primary or salvage therapy for Helicobacter pylori infection. Am J Gastroenterol 2002; 97: 857-60.

20. Gokcan H, Oztas E, Onal IK. Different bismuth-based therapies for eradicating Helicobacter pylori: Randomized clinical trial of efficacy and safety. Clin Res Hepatol Gastroenterol 2016; 40: 124-31.

21. Unler GK, Teke Ozgur G, Gokturk HS, Karakoca A, Erinanc OH. A Comparison of Five Different Treatment Regimens as the FirstLine Treatment of Helicobacter pylori in Turkey. Helicobacter 2016; 21: 279-85.

22. Kekilli M, Onal IK, Ocal S, Dogan Z, Tanoglu A. Inefficacy of triple therapy and comparison of two different bismuth- containing quadrupleregimens as a firstline treatment option for helicobacter pylori. Saudi J Gastroenterol 2016; 22: 366-9.

23. Lee $\mathrm{H}$, Hong $\mathrm{SN}$, Min BH, Lee JH, Rhee $\mathrm{PL}$, Lee $\mathrm{YC}$, et al. Comparison of efficacy and safety of levofloxacin-containing versus standard sequential therapyin eradication of Helicobacter pylori infection in Korea. Dig Liver Dis 2015; 47: 114-8.

24. Romano M, Cuomo A, Gravina AG, Miranda A, lovene MR, Tiso $A$, et al. Empirical levofloxacin-containing versus clarithromycincontaining sequential therapy for Helicobacter pylori eradication: a randomised trial. Gut 2010; 59: 1465-70.

25. Aydin A, Oruc N, Turan I, Ozutemiz O, Tuncyurek M, Musoglu A. The modified sequential treatment regimen containing levofloxacin for Helicobacter pylori eradication in Turkey. Helicobacter 2009; 14: 520-4. 